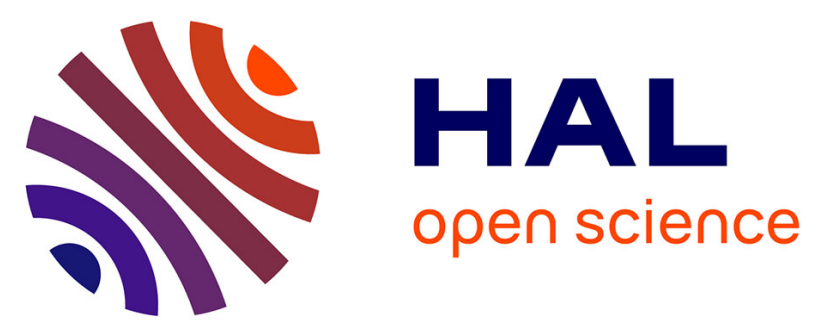

\title{
Exploring changes in dust particles size distribution on Mars during 2018 Global Dust Storm with a 3D Global Climate Model
}

Tanguy Bertrand, Melinda Kahre, John Wilson, Mike Wolff, Robert Haberle, Franck Montmessin, Richard Urata, Victoria Hartwick, Alex Kling, Amanda Brecht, et al.

\section{To cite this version:}

Tanguy Bertrand, Melinda Kahre, John Wilson, Mike Wolff, Robert Haberle, et al.. Exploring changes in dust particles size distribution on Mars during 2018 Global Dust Storm with a 3D Global Climate Model. Europlanet Science Congress 2020, Sep 2020, Virtual Meeting, Germany. pp.EPSC2020-518. insu-02919176

\section{HAL Id: insu-02919176 \\ https://hal-insu.archives-ouvertes.fr/insu-02919176}

Submitted on 21 Aug 2020

HAL is a multi-disciplinary open access archive for the deposit and dissemination of scientific research documents, whether they are published or not. The documents may come from teaching and research institutions in France or abroad, or from public or private research centers.
L'archive ouverte pluridisciplinaire HAL, est destinée au dépôt et à la diffusion de documents scientifiques de niveau recherche, publiés ou non, émanant des établissements d'enseignement et de recherche français ou étrangers, des laboratoires publics ou privés. 
EPSC Abstracts

Vol.14, EPSC2020-518, 2020

Europlanet Science Congress 2020

(C) Author(s) 2020. This work is distributed under

the Creative Commons Attribution 4.0 License.

\title{
Exploring changes in dust particles size distribution on Mars during 2018 Global Dust Storm with a 3D Global Climate Model
}

\author{
Tanguy Bertrand ${ }^{1}$, Melinda Kahre ${ }^{1}$, John Wilson ${ }^{1}$, Mike Wolff ${ }^{2}$, Robert M Haberle ${ }^{1}$, Franck \\ Montmessin ${ }^{3}$, Richard Urata ${ }^{1}$, Victoria Hartwick ${ }^{1}$, Alex Kling ${ }^{1}$, Amanda Brecht ${ }^{1}$, Kathryn Steakley ${ }^{1}$, \\ and Courntey Batterson ${ }^{1}$ \\ ${ }^{1}$ NASA Ames Research Center, Mountain view, United States of America (tanguy.bertrand@nasa.gov) \\ ${ }^{2}$ Space Science Institute, Boulder, CO 80301, US \\ ${ }^{3}$ LATMOS/IPSL, UVSQ Université Paris-Saclay, UPMC Univ. Paris 06, CNRS, Guyancourt, France
}

The 2018 Global Dust Storm (GDS) has been observed on Mars from the surface and from orbit. Here we focus on the surface temperatures measured locally by REMS/MSL in Gale crater and column dust IR opacities observed globally by Mars Climate Sounder on-board Mars Reconnaissance Orbiter (MCS/MRO) (e.g. Montabone et al., 2020). Recent modeling efforts of the 2018 GDS highlight that climate models do not simultaneously capture both the evolution of surface temperatures and the decay rate of global column dust opacities, which suggests that significant changes in dust particle sizes may occur during the dust storm (e.g. Bertrand et al., 2020, Montabone et al., 2020). These models typically assume a constant lifted dust particle size-with size evolution occurring in the atmosphere but only because of gravitational sedimentation. For instance, simulations with sufficiently large particles sizes to yield reasonable decay/sedimentation rates also provide excessive radiation fluxes at the surface, with excessive surface temperatures during peak dust loading.

One possible way to improve the agreement between the simulations and the observations is to allow the dust particle sizes to change more significantly in time and/or space during the simulated GDS. Particle size evolution toward large radius during GDSs is supported by several observations (e.g. Elteto and Toon, 2010, Lemmon et al., 2019). Different mechanisms could take place during dust storms to shift the dust particle distribution towards a larger effective radius: (1) the lifted particle size at the surface could change due to different active reservoirs or due to depletion of small particles as the storm increases in intensity and (2) the particle size in the atmosphere could change more significantly due to Brownian coagulation (production of large particles by the collisions induced by Brownian motions of the particles in the gas and subsequent sticking together of small particles) and gravitational coagulation (accretion through sedimentation, Murphy et al., 1990, Jacobsen et al., 1999, Montmessin et al., 2002, Fedorova et al., 2014). Previous studies have explored the impact of coagulation processes and concluded that coagulation only affects smaller particles ( $<0.1$ micron) and impacts dust opacities by only a few percent during dust storms (e.g. Murphy et al., 1990). However, these processes have never been explored with a full 3D GCM. 
the 2018 Global Dust Storm. We will build our investigation upon the previous modeling of the GDS performed with a uniform lifted effective particle radius (Bertrand et al., 2020). That study revealed that the dust number density during the dust storm is 100 times higher than during non-storm conditions, and should thus favor coagulation processes. We will show how these mechanisms impact the particle size distribution during the GDS, the surface temperature, the evolution and the decay phase of the storm, and explore what possible scenarios could reconcile the different observations.

\section{References}

Bertrand, T., Wilson, R. J., Kahre, M. A., Urata, R., \& Kling, A. ( 2020). Simulation of the 2018 Global Dust Storm on Mars Using the NASA Ames Mars GCM: A Multi $\square$ Tracer Approach. Journal of Geophysical Research: Planets, 125, e2019JE006122. https://doi.org/10.1029/2019JE006122

Elteto, A., \& Toon, O. B. (2010). The effects and characteristics of atmospheric dust during martian global dust storm 2001A. Icarus, 210(2), 589-611. https://doi.org/https://doi.org/10.1016/j.icarus.2010.07.011

Fedorova, A. A., Montmessin, F., Rodin, A. V., Korablev, O. I., Määttänen, A., Maltagliati, L., \& Bertaux, J. L. (2014). Evidence for a bimodal size distribution for the suspended aerosol particles on mars. Icarus, 231, 239-260. https://doi.org/10.1016/j.icarus.2013.12.015

Jacobsen, M.Z., 1999. Fundamentals of Atmospheric Modeling. Cambridge University Press. 656.

Lemmon, M. T., Guzewich, S. D., McConnochie, T., de Vicente $\square$ Retortillo, A., Martínez, G., Smith, M. D., et al. ( 2019). Large dust aerosol sizes seen during the 2018 Martian global dust event by the Curiosity rover. Geophysical Research Letters, 46, 9448- 9456. https://doi.org/10.1029/2019GL084407

Montabone, L., Spiga, A., Kass, D. M., Kleinböhl, A., Forget, F., \& Millour, E. ( 2020). Martian Year 34 Column Dust Climatology from Mars Climate Sounder Observations: Reconstructed Maps and Model Simulations. Journal of Geophysical Research: Planets, 125, e2019JE006111. https://doi.org/10.1029/2019JE006111

Montmessin, F., P. Rannou, and M. Cabane, 2002: New insights into Martian dust distribution and water-ice cloud microphysics, J. Geophys. Res., 107(E6), 5037, doi:10.1029/2001JE001520

Murphy, J. R., Toon, O. B., Haberle, R. M., \& Pollack, J. B., Numerical simulations of the decay of Martian global dust storms, Journal of Geophysical Research, , 95, p. 14629-14648, 1990. 